\title{
Orman Bölge Müdürlükleri açık artırmalı satışlarına katılan alıcıların beklentileri: Marmara Bölgesi örneği
}

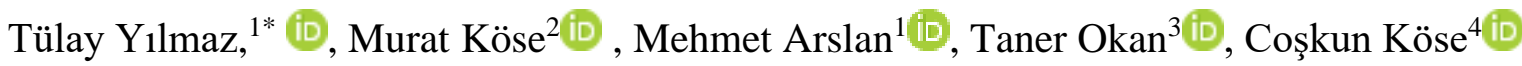 \\ 1 *Marmara Ormancılık Araştırma Enstitüsü Müdürlüğ̈̈, İstanbul, Türkiye \\ ${ }^{2}$ Çanakkale Onsekiz Mart Üniversitesi, Bayramiç Meslek Yüksekokulu, Çanakkale, Türkiye \\ ${ }^{3}$ Istanbul Üniversitesi-Cerrahpaşa, Orman Fakültesi, Orman Mühendisliği Bölümü, İstanbul, Türkiye \\ ${ }^{4}$ Istanbul Üniversitesi-Cerrahpaşa, Orman Fakültesi, Orman Endüstri Mühendisliği Bölümü, İstanbul, Türkiye
}

Sorumlu yazar: tulay.yilmaz.orem@gmail.com

\section{Özet}

$\mathrm{Bu}$ çalışmada, Devlet Orman İşletmelerinden odun hammaddesi satın alan müşterilerin odun tedarik sürecine ilişkin beklentilerinin tespit edilmesi amaçlanmıştır. Bu amaçla veriler, İstanbul, Bursa, Sakarya ve Çanakkale Orman Bölge Müdürlüklerinden açık artırmalı satışlar kapsamında odun hammaddesi satın alan 265 alıcı ile öncelikle yüz yüze görüşme yapılmak suretiyle anket tekniğinden yararlanılarak toplanmıştır. Çalışmada elde edilen veriler tanımlayıcı istatistiklerden frekanslar ve yüzde oranları ile değerlendirilmiştir. Çalışmada, açık artırmalı satışlara katılan firmaların on altı farklı ilde faaliyet gösterdiği, yaklaşık olarak yarısının şahıs ve aile firması olduğu, \%65'inin birincil imalat sanayinde, \%35'inin ise ikincil imalat sanayinde faaliyet gösterdiği belirlenmiştir. Firmaların, endüstriyel odun hammaddesi talebini karşıladıkları kaynaklara bakıldığında ilk sırada OGM Piyasa Satışları gelmektedir. Tüm OBM'lerine bakıldığında alıcılar genellikle karaçam, kayın ve göknar ağaç türlerini tercih etmektedirler. Açık artırmalı satışlarda ürün çeşidi olarak en fazla talep edilen \% 78 oranında tomruk olmuştur. Alıcılar hammadde fiyatlarını ve dikili satış uygulamalarını olumsuz yönde değerlendirmektedir.

Anahtar Kelimeler: Devlet Orman İşletmeleri, odun hammaddesi, dikili satış, müşteri tercihleri

\section{Expectations of buyers participating in auction sales of forest regional directorates: Case study of Marmara Region}

\begin{abstract}
In this study, it is aimed to determine the expectations of customers who buy wood raw materials from State Forestry Enterprises regarding the wood procurement process. For this purpose, with primarily on based face-toface interview technique, the data were collected taking advantage of the survey technique with the 265 buyers purchasing wood raw materials from the Istanbul, Bursa, Sakarya and Çanakkale Forestry Regional Directorates. The data obtained in the study were evaluated with descriptive statistics. In the study, it has determined that the companies participating in the sale operate in sixteen different provinces, approximately half of them operate as private or family enterprises, $65 \%$ in the primary manufacturing industry and $35 \%$ are in the secondary manufacturing industry. When the sources, where companies meet their industrial wood raw material demands, are examined, GDF Market Sales comes first. Considering all FRD, buyers generally prefer black pine, beech and fir tree species. In the auction sales, timber has been the most demanded product with $78 \%$. Buyers negatively evaluate raw material prices and stumpage sales practices.
\end{abstract}

Keywords: State Forest Enterprises, Wood raw material, stumpage sale, customer preferences. 


\section{Giriş}

Türkiye'de, toplumun odun ve odun dışı orman ürünlerine olan ihtiyaçlarını karşılamak üzere kurulan ve bu faaliyetlerini sürekli olarak gerçekleştiren Devlet Orman İşletmeleri (DOİ) odun hammaddesi üretiminin en önemli arz kaynağı durumundadır. Orman Genel Müdürlüğü (OGM) bünyesinde işletmecilik faaliyetlerini sürdüren DOİ, yakın zamana kadar piyasada odun üretimini büyük oranda karşılarken, günümüzde ithalatçı firmaların piyasaya mal temin etmesiyle birlikte rekabet etme, kaliteli üretim, maliyet vb. konularda darboğazlarla karşı karşıya kalmıştır. Türkiye orman ürünleri sektöründe öncül konumunu devam ettiren OGM, monopol olmanın avantajıyla sahip olduğu müşterilerin taleplerini dikkate almaksızın üretim yapmıştır (Türker, 1995; Türker, 1996; Daşdemir, 2001; Daşdemir, 2003; Öztürk, 2010; OGM, 2016a). 1990'lı y1lların başından itibaren etkili olmaya başlayan küreselleşme hareketleri ve Sovyetler Birliği'nin dağılması ile birçok yeni bağımsız ülkenin ortaya çıkması ve bu ülkelerin yaşadığı siyasi ve ekonomik gelişmeler orman ürünleri ticareti konusunda da ortaya çıkarak düşük fiyatlarda ithalatın önünü açmıştır. Tekel olma özelliğini yitirmeye başlayan OGM, pazarlama karmasının temel bileşenlerini oluşturan mal, fiyat, tutundurma ve dağıtım açısından eleştiri konusu olmuştur. DOİ, uzun yıllardır endüstriye uygun standart, kalite ve fiyatta hammadde teminini yerine getirememektedir (İlter ve Ok, 2012). Orman işletmeciliğinde geleneksel üretim ve pazarlama anlayışıyla piyasaya emval sunulmasının rasyonel ve verimli bir işletmecilik olmaktan çıktı̆̆ı, maliyet, kalite ve zaman açısından önemli kayıpların oluştuğu ifade edilmektedir (OGM, 2016b).

Bu kapsamda müşteri istek ve taleplerinin dikkate alınması ve müşteri odaklı bir pazarlama anlayışının gereklerinin yapılması gerektiği yapılan çalışmalarda ifade edilmektedir (Türker, 1996; Ok, 1997; Daşdemir, 2003; Dilsiz, 2008; Öztürk, 2010; Kök, 2010; Buğday, 2016; Çok ve ark., 2017; Özen ve Alkan, 2020). Bu çalışma ile Marmara Bölgesi sınırları içinde yer alan İstanbul, Bursa, Çanakkale ve Sakarya Orman Bölge Müdürlükleri (OBM) bünyesindeki DOİden ürün temin eden müşterilerin odun hammaddesi temin sürecine ilişkin beklentileri ortaya konulmuştur.

\section{Materyal ve Yöntem}

Bu çalışmanın materyali, alıcılara uygulanan Açık Artırmalı Satış Anketi ve araştırma kapsamındaki Orman Bölge Müdürlüklerinin İşletme Pazarlama Şube Müdürlükleri müşteri kayıtlarından oluşmaktadır. Anket sorularını oluşturabilmek amacıyla, makale konusuyla ilgili daha önce benzer amaçla yapılan çalışmalardan (Türker, 1996; Daşdemir, 2003; Dilsiz, 2008; Öztürk, 2010; Kök, 2010; Çok ve ark., 2017) materyal olarak faydalanılmıştır. Uygulanan anket kapalı uçlu soruların çoğunlukta olduğu 44 sorudan oluşmaktadır. Çalışmanın yapıldığı OBM ve bunlara bağlı DOİ Tablo 1'de gösterilmiştir. Buna göre çalışma alanında 4 OBM'ye bağlı 32 DOİ yer almaktadır.

Tablo 1. Çalıșmaya dahil edilen OBM ve ilgili DOİ

Table 1. Forest Regional Directorates and related State Forest Enterprises included in the study

\begin{tabular}{ll}
\hline OBM & Orman İşletme Müdürlükleri \\
\hline İstanbul & Bahçeköy, Çatalca, Demirköy, Edirne, İstanbul, Kanlıca, Kırklareli, Şile, Tekirdağ, Vize \\
Bursa & Yalova, Bilecik, Bursa, İnegöl, Keles, Mustafakemalpaşa, Orhaneli \\
Çanakkale & Ayvacık, Keşan, Bayramiç, Biga, Çanakkale, Çan, Kalkım, Yenice \\
Sakarya & Adapazarı, Akyazı, Hendek, Geyve, Karasu, İzmit, Gölcük
\end{tabular}

Anket uygulanılacak evrendeki toplam alıcı sayısı müşteri kayıtlarından 785 olarak tespit edilmiştir (Tablo 2). Sınırlı toplumlarda örneklem büyüklüğü formülü kullanılarak anket yapılacak alıcı sayısı minimum 258 olarak öngörülmüştür. Ardından, Tesadüfü Örnekleme Yöntemlerinden biri olan Zümrelere Göre Örnekleme Yöntemi kullanılarak orantılı seçim yapılmış ve OBM'lere göre yapılacak anket sayısı hesaplanmıştır (Orhunbilge, 2000). Buna göre; çalışma kapsamında, dört Orman Bölge Müdürlüğü ihalelerine katılan toplam 265 adet endüstriyel alıcı ile anket çalışması yapılmıştır. Anketlerin \%49'u Bursa OBM, \%18'i Sakarya OBM, \%17'si İstanbul OBM ve \%16'sı ise Çanakkale 
OBM alıcıları ile gerçekleştirilmiştir (Tablo 2). Anket çalışmasına katılan alıcıların \%74'ü firma sahibi, \%26'sı ise firma çalışanıdır. Birden fazla ihaleye katılan müşterilerle bir kez anket yapılmıştır.

Tablo 2. Çalışmada yapılan anket sayısı

Table 2. Participants number of the study

\begin{tabular}{lcccc}
\hline OBM & $\begin{array}{c}\text { Alıcı Firma } \\
\text { Sayısı }\end{array}$ & $\begin{array}{c}\text { Öngörü̈len } \\
\text { Anket sayısı }\end{array}$ & $\begin{array}{c}\text { Yapılan } \\
\text { Anket Sayısı }\end{array}$ & $\begin{array}{c}\text { Yüzde } \\
(\%)\end{array}$ \\
\hline Bursa & 394 & 129 & 129 & 49 \\
Çanakkale & 127 & 41 & 41 & 16 \\
İstanbul & 116 & 40 & 46 & 17 \\
Sakarya & 148 & 48 & 49 & 18 \\
Toplam & 785 & 258 & 265 & 100 \\
\hline
\end{tabular}

Devlet ormanlarından üretilen her türlü endüstriyel odun ile yakacak odun ve odun dişı ürünler 6831 sayılı Orman Kanunu'nun 30., 31., 32., 33., 34. ve 37'inci maddeleri ile bazı özel kanunların özel hükümleri uyarınca pazarlanmaktadır (OGM, 2016b). 6831 Sayı1ı Orman Kanunu'nun 30. Maddesine göre devlet ormanlarından elde edilen ürünler; a) Açık artırmalı satışlar, b) Tahsisli satışlar olmak üzere iki satış metodu ile satılmaktadır. Orman Kanunun 31., 32., 33. ve 34. maddeleri ile orman köylüsü ve kooperatiflerine yapılan indirimli satışları düzenlenmektedir. Bu çalışmada, 30. Maddede belirtilen açık artırmalı satışlardan emval alan alıcılar kapsama dâhil edilmiştir.

Anketlerin yapılabilmesi için ihaleler takip edilmiş ve hangi ihalelere katılım sağlanacağı konusunda bir planlama yapılmıştır. Anketlerin uygulanmasında öncelikle karşılıklı (yüz yüze) görüşme yöntemi tercih edilmiştir. İhaleler sırasında müşterilerin ankete zaman ayıramama vb. sıkıntıların yaşandığı durumlarda ise söz konusu müşteriler ile iş yerlerinde görüşmeler yapılmıştır.

Çalışmada anket uygulamaları sonucu elde edilen veri seti analiz amaciyla bilgisayar ortamına aktarılmıştır. Elde edilen veriler SPSS (2012) paket programı kullanılarak değerlendirilmiştir. Değerlendirme yöntemi olarak, frekanslar ve yüzde oranları vb. betimleyici istatistiklerden yararlanılmıştır. Betimleyici istatistik, daha çok verileri tanımlamak özetlemek ve mevcut yapıyı ortaya koymak amacıyla kullanılmaktadır (Daşdemir, 2016).

\section{Bulgular}

\subsection{Alıcı Firmaların Genel yapısı}

Çalışmaya katılan firmaların kurulu bulundukları illere göre dağılımı Tablo 3'te gösterilmiştir. Çalışma alanında açık artırmalı satışlara katılan firmalar; Bursa, Çanakkale, İstanbul, Adapazarı, İzmit, Yalova, Edirne, Tekirdağ, Kırklareli, Balıkesir başta olmak üzere "diğer" seçeneğini işaretleyen İzmir, Zonguldak, Bolu, Konya Düzce illerindeki firmalar ile birlikte 16 farklı ilde faaliyet göstermektedir (Tablo 3). Firmaların daha çok kendi bulunduğu il sınırı içindeki bölge müdürlüğü ihalelerini tercih ettiği görülmektedir. Bölge müdürlüğü dışındaki illerden ihalelere katılan firmalar da azımsanmayacak sayıdadır. İhalelere katılım şekli olarak değerlendirdiğimizde bölgesel katılım ağırlıklı olmakla birlikte çevre illerden de katılım mevcuttur.

Çalışmaya katılan firmaların hukuki yapıları Tablo 4'te gösterilmiştir. Buna göre, firmaların genel toplamda $\% 49,8$ 'sinin şahıs ve aile firması, \%37,7'sinin limited şirket, \%10,6'sının anonim şirket ve $\% 1,9$ 'unun ise kooperatif olduğu belirlenmiştir.

Çalışmaya katılan firmaların \%65'i odunu doğrudan hammadde olarak kullanan birincil imalat sanayi (örneğin kereste ve parke sektörü, kaplama ve kontrplak, yonga ve lif levha endüstrisi) sınıfina girmektedir. Firmaların \%35'i ise ikincil imalat sanayi (Mobilya, doğrama, ahşap parke, prefabrik ev, palet, ambalaj vb.) içinde yer almaktadır (Tablo 5). Firmaların ait oldukları alt sektörler detaylı olarak incelendiğinde birincil imalat sanayi grubunda kereste üreticileri, ikincil imalat sanayi grubunda ise palet üreticileri öne çıkmaktadır. 
Tablo 3. Firmaların bulundukları illere göre dağılımı

Table 3. Distribution of companies according to their provinces

\begin{tabular}{lcccccccccc}
\hline OBM & \multicolumn{2}{c}{ Bursa } & \multicolumn{2}{c}{ Çanakkale } & \multicolumn{2}{c}{ İstanbul } & \multicolumn{2}{c}{ Sakarya } & \multicolumn{2}{c}{ Toplam } \\
\hline Il & Sayı & \% & Sayı & \% & Sayı & \% & Sayı & \% & Sayı & $\%$ \\
\hline Bursa & 83 & 31 & 1 & 0 & - & - & 9 & 3 & 93 & 35 \\
Çanakkale & - & - & 34 & 13 & - & - & - & - & 34 & 13 \\
İstanbul & 8 & 3 & - & - & 15 & 6 & 2 & 1 & 25 & 10 \\
Adapazarı & 4 & 2 & - & - & - & - & 21 & 8 & 25 & 10 \\
İzmit & 1 & 0 & 1 & 0 & 8 & 3 & 9 & 3 & 19 & 6 \\
Yalova & 13 & 5 & - & - & - & - & - & - & 13 & 5 \\
Edirne & 3 & 1 & - & - & 7 & 3 & 2 & 1 & 12 & 4 \\
Tekirdağ & 4 & 2 & - & - & 8 & 3 & - & - & 12 & 5 \\
Diğer & 6 & 2 & - & - & - & - & 6 & 2 & 12 & 4 \\
Kırklareli & 1 & 1 & 1 & 0 & 8 & 3 & - & - & 10 & 4 \\
Balıkesir & 6 & 2 & 4 & 2 & - & - & - & - & 10 & 4 \\
Toplam & 129 & 49 & 41 & 16 & 46 & 17 & 49 & 19 & 265 & 100 \\
\hline
\end{tabular}

Tablo 4. Firmaların hukuki yapılarına göre dağılımı

Table 4. Distribution of companies according to their legal structures

\begin{tabular}{lcccccccc}
\hline Hukuki Yapı & \multicolumn{2}{c}{ Kooperatif } & Limited & \multicolumn{2}{c}{ Anonim } & \multicolumn{3}{c}{ Şahıs ve Aile } \\
\hline OBM & Sayı & \% & Sayı & \% & Sayı & \% & Sayı & \% \\
\hline Bursa & 5 & 1,9 & 54 & 20,4 & 15 & 5,7 & 55 & 20,8 \\
Çanakkale & - & - & 12 & 4,5 & 5 & 1,9 & 24 & 9,1 \\
İstanbul & - & - & 19 & 7,2 & 2 & 0,7 & 25 & 9,4 \\
Sakarya & - & - & 15 & 5,6 & 6 & 2,3 & 28 & 10,6 \\
Toplam & 5 & 1,9 & 100 & 37,7 & 28 & 10,6 & 132 & 49,8 \\
\hline
\end{tabular}

Tablo 5. Firmaların sektörlere göre dağılımı

Table 5. Distribution of companies by industries

\begin{tabular}{lcccc}
\hline İmalat Türü & \multicolumn{2}{c}{ Birincil İmalat } & \multicolumn{2}{c}{ İkincil İmalat } \\
\hline OBM & Sayı & \% & Sayı & $\%$ \\
Bursa & 89 & 35 & 40 & 15 \\
Çanakkale & 30 & 11 & 11 & 4 \\
İstanbul & 27 & 10 & 19 & 7 \\
Sakarya & 25 & 9 & 24 & 9 \\
Toplam & 171 & 65 & 94 & 35 \\
\hline
\end{tabular}

Çalışmaya katılan firmaların kapasiteleri için verdikleri bilgiler Tablo 6' da gösterilmiştir. Kapasitesi 0$1000 \mathrm{~m}^{3}$ arası olan işletmelerin oran1 \%18' dir. Kapasitesi 1001-3000 m³/y1l olan işletmeler ise \%30 oranı ile ilk sırada yer almaktadır. Kapasitesi 3001-6000 m³/yıl olan işletmeler \%12 oranındadır. Kapasitesi $6001-9000 \mathrm{~m}^{3} / \mathrm{y} 1 \mathrm{l}$ arasında olan işletmeler ise \%9 oranındadır. Kapasitesi 120001-15000 $\mathrm{m}^{3} / \mathrm{y} 1 \mathrm{l}$ olan işletmelerin oranı \%8'dir. Kapasitesi $150001-50000 \mathrm{~m}^{3} / \mathrm{y} 1 \mathrm{l}$ arası olan işletmeler ise \%13 oranında bir paya sahiptir.

Tablo 6. Firmaların ürün işleme kapasiteleri $\left(\mathrm{m}^{3} / \mathrm{yll}\right)$

Table 6. Product processing capacities of companies ( $\mathrm{m}^{3} /$ years)

\begin{tabular}{lcccccccccc}
\hline OBM & \multicolumn{2}{c}{ Bursa } & \multicolumn{2}{c}{ Çanakkale } & \multicolumn{2}{c}{ İstanbul } & \multicolumn{2}{c}{ Sakarya } & \multicolumn{2}{c}{ Toplam } \\
\hline Kapasite & Sayı & $\%$ & Sayı & \% & Sayı & \% & Sayı & \% & Sayı & \% \\
\hline $0-1000$ & 30 & 11 & 6 & 2 & 4 & 2 & 8 & 3 & 48 & 18 \\
$1001-3000$ & 36 & 14 & 13 & 5 & 18 & 6 & 12 & 5 & 79 & 30 \\
$3001-6000$ & 17 & 6 & 4 & 2 & 6 & 2 & 5 & 2 & 32 & 12 \\
$6001-9000$ & 8 & 3 & 8 & 3 & 4 & 2 & 2 & 1 & 22 & 8 \\
$9001-12500$ & 11 & 4 & 6 & 2 & 5 & 2 & 8 & 3 & 30 & 11 \\
$12501-15000$ & 10 & 4 & 2 & 1 & 5 & 2 & 3 & 1 & 20 & 8 \\
$15001-50000$ & 17 & 6 & 2 & 1 & 4 & 2 & 11 & 4 & 34 & 13 \\
Toplam & 129 & 49 & 41 & 16 & 46 & 17 & 49 & 19 & 265 & 100 \\
\hline
\end{tabular}


Firmaların Kapasite Kullanım Oranları (KKO) sorulduğunda verilen yanıtlar Tablo 7'de gösterilmiştir. Buna göre; firmaların \%73'ü KKO açısından \%76-100 aralığında, \%18'i \%26-50 aralığında, \%8'i ise \%51-75 aralığındadır (Tablo 7).

Tablo 7. Firmaların kapasite kullanım oranları

Table 7. Capacity usage ratio of companies

\begin{tabular}{lcccccccccc}
\hline OBM & \multicolumn{2}{c}{ Bursa } & \multicolumn{2}{c}{ Çanakkale } & \multicolumn{2}{c}{ İstanbul } & \multicolumn{2}{c}{ Sakarya } & \multicolumn{2}{c}{ Toplam } \\
\hline KKO $(\%)$ & Sayı & \% & Sayı & \% & Sayı & \% & Sayı & \% & Sayı & \% \\
\hline $0-25$ & 1 & 0 & - & - & - & - & - & - & 1 & 0,3 \\
$26-50$ & 16 & 6 & 21 & 8 & 8 & 3 & 2 & 1 & 47 & 17,7 \\
$51-75$ & 14 & 5 & 8 & 3 & 1 & 0 & 1 & 0 & 24 & 9 \\
$76-100$ & 98 & 37 & 12 & 5 & 37 & 14 & 46 & 17 & 193 & 73 \\
Toplam & 129 & 48 & 41 & 16 & 46 & 17 & 49 & 18 & 265 & 100 \\
\hline
\end{tabular}

\subsection{Alıcıların Endüstriyel Odun Hammaddesi Satın Alma Tercihleri}

Firmaların, endüstriyel odun hammaddesi talebini karşıladıkları kaynaklara bakıldığında birinci tercih olarak, "OGM piyasa satışları" \%68 ile ilk sırada yer almaktadır. İkinci sırada "ithal ürünler" ve üçüncü sırada ise \%8 ile "tahsisli satışlar" gelmektedir (Şekil 1). Firmaların \%5 oranında doğrudan ithalat yapmaları da değerlendirildiğinde ithalatın hammadde talebini karşılamadaki yeri \%20'ye çıkmaktadır.

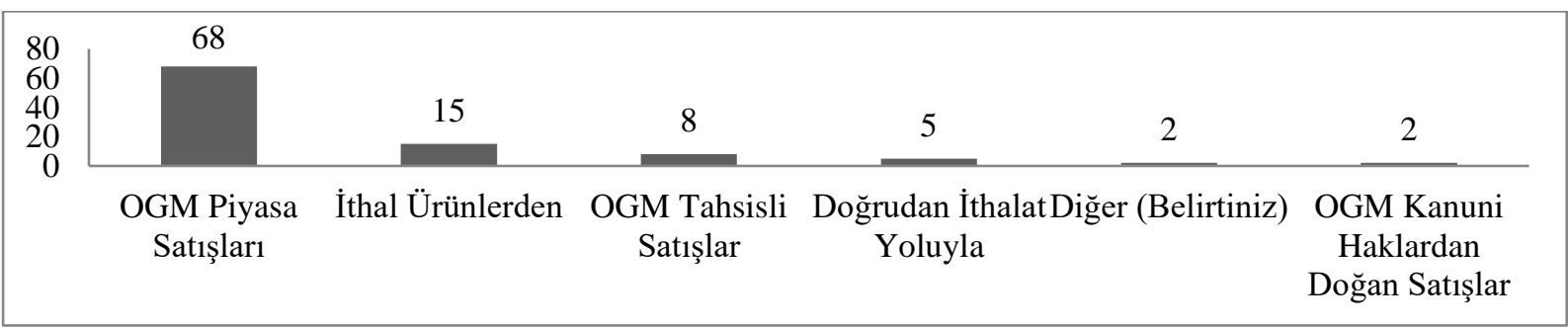

Şekil 1. Firmaların endüstriyel odun hammaddesi talebini karşılama seçenekleri

Figure 1. Options of the companies' the industrial wood raw material demand meet

Çalışmaya katılan firmaların, endüstriyel odun hammaddesi talebini ithalat yoluyla karşılama nedenleri sorulduğunda, \%27 ile "Hammadde Fiyatlarının Uygunluğu" öne çıkmaktadır (Şekil 2). İthalat yapma nedenleri arasında "istenilen kalitede ürün bulma" \%25 ile ikinci sırada, "istenilen zamanda ürün bulma" ise \%21 ile üçüncü sırada yer almaktadır. Diğer yandan, ithalat yapan ve ithal hammadde kullanan firmalara alım miktarına göre ithalatta tercih ettikleri ülkeler sorulduğunda, Ukrayna, Bulgaristan ve Rusya öne çıkmaktadır.

\begin{tabular}{|c|c|c|c|c|c|c|}
\hline \multirow[t]{2}{*}{$\begin{array}{r}30 \\
20 \\
10 \\
0\end{array}$} & 27 & 25 & 21 & 16 & 10 & 1 \\
\hline & $\begin{array}{l}\text { Hammadde } \\
\text { fiyatlarının } \\
\text { uygunluğu }\end{array}$ & $\begin{array}{l}\text { İstenilen kalitede } \\
\text { ürün bulunması }\end{array}$ & $\begin{array}{l}\text { İstenilen } \\
\text { zamanda ürün } \\
\text { bulunması }\end{array}$ & $\begin{array}{c}\text { İstenilen } \\
\text { ebatlarda ürün } \\
\text { bulunması }\end{array}$ & $\begin{array}{l}\text { OGM'nin üretim } \\
\text { ve satış } \\
\text { politikalarından }\end{array}$ & $\begin{array}{c}\text { Diğer } \\
\text { (Belirtiniz) }\end{array}$ \\
\hline
\end{tabular}

Şekil 2. İthal ürün kullanma nedenleri

Figure 2. Reasons for using imported products

\subsection{Alıcıların Satın Aldıkları Ürünlere İlişkin Tercihleri}

Alıcılara hangi ağaç türlerini tercih ettikleri sorulduğunda, tüm OBM'ler itibariyle karaçam (\%39), kayın (\%30) ve göknar (\%12) öne çıkmaktadır (Tablo 8). 
Tablo 8. Alıcıların tercih ettikleri ağaç türleri

Table 8. Buyers' preferred tree types

\begin{tabular}{lcc}
\hline Ăgaç Türü & Sayı & \% \\
\hline Karaçam & 99 & 39 \\
Kayın & 77 & 30 \\
Göknar & 30 & 12 \\
Meşe & 21 & 8 \\
Kızılçam & 21 & 8 \\
Sarıçam & 2 & 1 \\
Farketmez & 4 & 2 \\
Diğer & 1 & 0 \\
\hline
\end{tabular}

Firmalara alım miktarına göre en çok hangi DOI'deki ihaleye katıldıkları sorulmuş ve alınan yanıtlar Tablo 9'da verilmiştir. Sakarya OBM alıcıları sırasıyla, Akyazı, Adapazarı, Bolu ve Hendek; Bursa OBM müşterileri İnegöl, Bursa ve Mustafakemalpaşa; Çanakkale OBM alıcıları Ayvacık, Kalkım, Çan ve Yenice; İstanbul OBM alıcıları ise sırasıyla Kanlıca, Bahçeköy ve Demirköy DOİ'deki açık artırmalı satışları tercih etmektedir.

Tablo 9. Alıcıların hammadde temininde tercih ettikleri DOİ

Table 9. State Forestry Enterprises preferred by buyers for raw material procurement

\begin{tabular}{lccc}
\hline \multicolumn{3}{c}{ Orman İşletme Müdürlükleri } \\
\hline OBM & 1. Tercih & 2. Tercih & 3. Tercih \\
\hline Sakarya & Akyazı & Adapazarı, Bolu & Hendek \\
Bursa & İnegöl & Bursa & Mustafakemalpaşa \\
Çanakkale & Ayvacık & Kalkım & Çanakkale, Çan, Yenice \\
İstanbul & Kanlıca & Bahçeköy & Demirköy \\
\hline
\end{tabular}

Alıcılara talep ettikleri satış parti büyükleri sorulduğunda, ilk sırada $\% 53$ ile $21-40 \mathrm{~m}^{3}$, ikinci sırada $\% 27$ ile 41-60 $\mathrm{m}^{3}$ satış parti büyüklüğü gelmektedir (Tablo 10).

Tablo10. Alıcıların satışlarda talep ettikleri satış parti büyüklükleri

Table 10. Sales lot sizes requested by buyers in sales

\begin{tabular}{lcccccccccc}
\hline OBM & \multicolumn{1}{c}{ Bursa } & \multicolumn{3}{c}{ Çanakkale } & \multicolumn{2}{c}{ İstanbul } & \multicolumn{2}{c}{ Sakarya } & \multicolumn{2}{c}{ Toplam } \\
\hline $\mathbf{( m}^{\mathbf{3})}$ & Sayı & $\mathbf{\%}$ & Sayı & $\boldsymbol{\%}$ & Sayı & $\boldsymbol{\%}$ & Sayı & \% & Sayı & $\%$ \\
\hline $0-10$ & 1 & 0 & 2 & 1 & - & - & - & - & 3 & 1 \\
$11-20$ & 8 & 3 & 7 & 3 & 1 & - & 1 & - & 17 & 6 \\
$21-40$ & 65 & 25 & 16 & 6 & 33 & 13 & 27 & 10 & 141 & 53 \\
$41-60$ & 36 & 14 & 11 & 4 & 9 & 3 & 15 & 6 & 71 & 27 \\
61 ve üstü & 9 & 3 & 5 & 2 & - & - & 4 & 2 & 18 & 7 \\
Diğer & 8 & 3 & - & - & 3 & 1 & 2 & 1 & 15 & 6 \\
Toplam & 127 & - & 41 & - & 46 & - & 49 & - & 265 & 100 \\
\hline
\end{tabular}

Alıcıların ürün çeşitleri açısından tercihleri Tablo 11'de gösterilmiştir (Tablo 11). Açık artırmalı satışlarda ürün çeşidi olarak $\% 78$ oranında tomruk, $\% 9$ oranında sanayi odunu, $\% 8$ oranında lif-yonga odunu, $\% 4$ oranında kâğıtlık odun ve $\% 1$ oranında maden direk tercih edilmektedir.

Tablo 11. Alıcıların tercih ettikleri ürün çeşitleri

Table 11. Product types preferred by buyers

\begin{tabular}{lcc}
\hline Ürünler & Sayı & \% \\
\hline Tomruk & 203 & 78 \\
Sanayi Odunu & 22 & 9 \\
Lif yonga & 20 & 8 \\
Kăğtllk & 10 & 4 \\
Maden Direk & 3 & 1 \\
Toplam & 258 & 100 \\
\hline
\end{tabular}

Alıcılara emvalin alınacağı yere ilişkin tercihleri sorulmuştur (Tablo 12). Çalışmaya katılan alıcıların \%80'i emvali son depodan, \%14'ü rampadan, \%5'i ise maktadan satın almayı tercih etmektedir. 
Tablo 12. Alıcıların emvalin teslim alınacağı yere ilişkin tercihleri

Table 12. Buyers' preferences regarding the place to receive the assets

\begin{tabular}{lcccccccccc}
\hline OBM & \multicolumn{2}{c}{ Bursa } & \multicolumn{2}{c}{ Çanakkale } & \multicolumn{1}{c}{ İstanbul } & \multicolumn{2}{c}{ Sakarya } & \multicolumn{2}{c}{ Toplam } \\
\hline Tercihler & Sayı & \% & Sayı & \% & Sayı & \% & Sayı & \% & Sayı & \% \\
\hline Son Depo & 111 & 42 & 23 & 9 & 35 & 13 & 43 & 16 & 212 & 80 \\
Rampa & 11 & 4 & 11 & 4 & 10 & 4 & 6 & 2 & 37 & 14 \\
Makta & 6 & 2 & 6 & 2 & 1 & - & - & - & 13 & 5 \\
Diğer & 1 & 1 & 1 & - & - & - & - & - & 3 & 1 \\
Toplam & 129 & 49 & 41 & 16 & 46 & 17 & 49 & 18 & 265 & 100 \\
\hline
\end{tabular}

Alıcılara emvali hangi ayda satın almak istediklerine yönelik tercihleri sorulmuştur (Tablo 13). OBM alıcıları emvali satın almak istedikleri aya ilişkin olarak \%39 oranında "farketmez" tercihini kullanmışlardır.

Tablo 13. Alıcıların emvali satın almak istedikleri aylar

Table 13. Months when buyers want to buy the assets

\begin{tabular}{|c|c|c|c|c|c|c|c|c|c|c|}
\hline \multirow{2}{*}{$\begin{array}{l}\text { OBM } \\
\text { Tercihler }\end{array}$} & \multicolumn{2}{|c|}{ Bursa } & \multicolumn{2}{|c|}{ Çanakkale } & \multicolumn{2}{|c|}{ İstanbul } & \multicolumn{2}{|c|}{ Sakarya } & \multicolumn{2}{|c|}{ Toplam } \\
\hline & Sayı & $\%$ & Sayı & $\%$ & Sayı & $\%$ & Sayı & $\%$ & Sayı & $\%$ \\
\hline Ocak-Mart & 13 & 5 & 10 & 4 & - & - & 10 & 4 & 33 & 12 \\
\hline Nisan-Haziran & 30 & 11 & 6 & 2 & 8 & 3 & 11 & 4 & 55 & 21 \\
\hline Temmuz-Eylül & 13 & 5 & 6 & 2 & 3 & 1 & 5 & 2 & 27 & 10 \\
\hline Ekim-Aralik & 24 & 9 & 4 & 2 & 12 & 5 & 7 & 3 & 47 & 18 \\
\hline Farketmez & 49 & 18 & 15 & 6 & 23 & 9 & 16 & 6 & 103 & 39 \\
\hline Toplam & 129 & 49 & 41 & 16 & 46 & 18 & 49 & 19 & 265 & 100 \\
\hline
\end{tabular}

Çalışmaya katılan alıcılara ihale günlerinin düzenlenmesine yönelik tercihleri sorulmuştur (Tablo 14). Alıcıların \%15'i haftanın ilk günü ihalelerin düzenlenmemesini, \%15'i vergi vb. ödeme günlerinin ihalelere denk gelmemesini, \%5'i ise ihalenin, düzenlendiği ilçelerin yerel pazarı vb. günlerine denk gelmemesini talep etmişlerdir. Alıcıların, \%65'i "diğer" seçeneğini işaretleyenlerden oluşmaktadır. Diğer seçeneğini tercih edenlerden büyük çoğunluğu (\%90) cuma gününün ihale günü olmamasını talep etmişlerdir.

Tablo 14. Alıcıların ihale günlerinin düzenlenmesine yönelik tercihleri

Table 14. Buyers' preferences for the tender days' arrangement

\begin{tabular}{lcccccccccc}
\hline OBM & \multicolumn{2}{c}{ Bursa } & \multicolumn{3}{c}{ Çanakkale } & \multicolumn{2}{c}{ İstanbul } & \multicolumn{2}{c}{ Sakarya } & \multicolumn{2}{c}{ Toplam } \\
\hline İhale günleri tercihleri & Sayı & $\%$ & Sayı & \% & Sayı & \% & Sayı & \% & Sayı & \% \\
\hline Haftanın ilk günü olmasın & 14 & 5 & 12 & 5 & 8 & 3 & 5 & 2 & 39 & 14,7 \\
Vergi vb. ödeme günü olmasın & 15 & 6 & 12 & 5 & 8 & 3 & 4 & 2 & 39 & 14,7 \\
İlçe pazarı vb. günü olmasın & 8 & 3 & 6 & 2 & - & - & 1 & - & 15 & 5,6 \\
Diğer & 92 & 35 & 11 & 4 & 30 & 11 & 39 & 15 & 172 & 65 \\
Toplam & 129 & 49 & 41 & 16 & 46 & 17 & 49 & 19 & 265 & 100 \\
\hline
\end{tabular}

Çalışmaya katılan alıcılara ihale tarihlerinin düzenlenmesine yönelik tercihleri sorulmuştur. Alıcıların \%43'ü "yakın işletme müdürlüklerindeki ihaleler belirli aralıklarla yapılmalı" seçeneğini ilk sırada tercih etmektedir. İkinci tercih olarak \%28'i "aynı çeşit ürün üreten işletmelerin ihaleleri çakışmamalı" seçeneğini belirtmişlerdir (Tablo 15).

Alıcılara satış koşullarına ilişkin beklentileri sorulduğunda, ilk sırada \%44 ile "satış koşulları yılda bir kez belirlenmeli" seçeneği yer almaktadır (Tablo 16). Alıcıların \%26'sı ise "satış koşullarına ilişkin değişiklikler en az 3 ay önceden sektöre duyurulmalı" değerlendirmesini yapmıştır. Alıcıların \%24'ü ise karar sürecinde katılımlarının sağlanması gerektiğini ifade etmiştir.

Alıcıların önemli bir kısmı (\%88), satış partilerinin oluşturulmasında ince çaplı ve kalın çaplı hammaddenin ayrı ayrı partilerde yer almasını tercih etmişlerdir (Tablo 17). İnce çaplı ve kalın çaplı emvaller aynı satış partisinde karışık yer almalıdır tercihini yapanların oranı ise \%12'dir. 
Tablo 15. Alıcıların ihale tarihlerinin düzenlenmesine yönelik tercihleri

Table 15. Buyers' preferences for the tender date's arrangement

\begin{tabular}{|c|c|c|c|c|c|c|c|c|c|c|}
\hline \multirow{2}{*}{$\begin{array}{l}\text { OBM } \\
\text { Seçenekler }\end{array}$} & \multicolumn{2}{|c|}{ Bursa } & \multicolumn{2}{|c|}{ Çanakkale } & \multicolumn{2}{|c|}{ İstanbul } & \multicolumn{2}{|c|}{ Sakarya } & \multicolumn{2}{|c|}{ Toplam } \\
\hline & Sayı & $\%$ & Sayı & $\%$ & Sayı & $\%$ & Sayı & $\%$ & Sayı & $\%$ \\
\hline $\begin{array}{l}\text { Yakın işletme müdürlüklerindeki } \\
\text { ihaleler belirli aralıklarla yapılmalı }\end{array}$ & 56 & 21 & 16 & 6 & 24 & 9 & 18 & 7 & 114 & 43 \\
\hline $\begin{array}{l}\text { Aynı çeşit ürün üreten işletmelerin } \\
\text { ihaleleri çakışmamalı }\end{array}$ & 30 & 11 & 12 & 5 & 9 & 3 & 22 & 8 & 73 & 28 \\
\hline $\begin{array}{l}\text { Yakın işletme müdürlüklerindeki } \\
\text { ihaleler peş peşe olmalı }\end{array}$ & 29 & 11 & 9 & 3 & 9 & 3 & 4 & 2 & 51 & 19 \\
\hline Farketmez & 14 & 5 & 4 & 2 & 4 & 2 & 4 & 2 & 26 & 10 \\
\hline Diğer & - & - & - & - & - & - & 1 & 0 & 1 & 0 \\
\hline Toplam & 129 & 48 & 41 & 16 & 46 & 17 & 49 & 19 & 265 & 100 \\
\hline
\end{tabular}

Tablo 16. Alıcıların satış koşulları değişikliklerine ilişkin beklentileri

Table 16. Buyers' expectations of changes in conditions of sale

\begin{tabular}{|c|c|c|c|c|c|c|c|c|c|c|}
\hline OBM & \multicolumn{2}{|c|}{ Bursa } & \multicolumn{2}{|c|}{ Çanakkale } & \multicolumn{2}{|c|}{ İstanbul } & \multicolumn{2}{|c|}{ Sakarya } & \multicolumn{2}{|c|}{ Toplam } \\
\hline Seçenekler & Sayı & $\%$ & Sayı & $\%$ & Sayı & $\%$ & Sayı & $\%$ & Sayı & $\%$ \\
\hline Satış koşulları yılda bir kez belirlenmeli & 59 & 22 & 14 & 5 & 24 & 9 & 22 & 8 & 119 & 44 \\
\hline Değişiklikler en az 3 ay önceden sektöre duyurulmalı & 40 & 15 & 4 & 2 & 11 & 4 & 13 & 5 & 68 & 26 \\
\hline Alıcıların görüşleri alınmalı & 25 & 9 & 21 & 8 & 9 & 3 & 11 & 4 & 66 & 24 \\
\hline Diğer & 5 & 2 & 2 & 1 & 2 & 1 & 3 & 2 & 12 & 6 \\
\hline Toplam & 129 & - & 41 & - & 46 & - & 49 & - & 265 & 100 \\
\hline
\end{tabular}

Tablo 17. Alıcıların satış istiflerinin çaplarına yönelik tercihleri

Table 17. Buyers' preferences for the sale stowages' diameters

\begin{tabular}{|c|c|c|c|c|c|c|c|c|c|c|}
\hline OBM & \multicolumn{2}{|c|}{ Bursa } & \multicolumn{2}{|c|}{ Çanakkale } & \multicolumn{2}{|c|}{ İstanbul } & \multicolumn{2}{|c|}{ Sakarya } & \multicolumn{2}{|c|}{ Toplam } \\
\hline Çap Tercihleri & Sayı & $\%$ & Sayı & $\%$ & Sayı & $\%$ & Sayı & $\%$ & Sayı & $\%$ \\
\hline $\begin{array}{l}\text { İnce çaplı ve kalın çaplı emvaller ayrı ayrı } \\
\text { partilerde yer almalıdır }\end{array}$ & 110 & 41 & 37 & 14 & 41 & 16 & 44 & 17 & 233 & 88 \\
\hline $\begin{array}{l}\text { İnce çaplı ve kalın çaplı emvaller aynı } \\
\text { partide karışı yer almalıdır }\end{array}$ & 18 & 7 & 4 & 1 & 5 & 2 & 5 & 2 & 32 & 12 \\
\hline Toplam & 128 & 48 & 41 & 15 & 46 & 18 & 49 & 19 & 265 & 100 \\
\hline
\end{tabular}

Alıcılar, satış partilerinin oluşturulmasında emval boylarına ilişkin olarak \%61 oranında satış partilerinin tek boydan oluşmasını tercih etmektedirler. Buna karşın, satış partilerinin tüm boylardan oluşmasını ifade edenlerin oranı \%39'dur (Tablo 18).

Tablo 18. Alıcıların satıș istiflerinin boylarına yönelik tercihleri

Table 18. Buyers' preferences for the sale stowages' sizes

\begin{tabular}{lcccccccccc}
\hline OBM & \multicolumn{2}{c}{ Bursa } & \multicolumn{2}{c}{ Çanakkale } & \multicolumn{2}{c}{ İstanbul } & \multicolumn{2}{c}{ Sakarya } & \multicolumn{2}{c}{ Toplam } \\
\hline Boy Tercihleri & \% & Sayı & \% & Sayı & \% & Sayı & \% & Sayı & Sayı & \% \\
\hline Tek boy & 30 & 80 & 12 & 31 & 9 & 24 & 10 & 25 & 160 & 61 \\
Karışık boy & 18 & 48 & 4 & 10 & 8 & 21 & 9 & 24 & 103 & 39 \\
Toplam & 48 & 128 & 16 & 41 & 17 & 45 & 19 & 49 & 263 & 100 \\
\hline
\end{tabular}

Alıcıların ağaç türleri itibariyle tomruk boy uzunluğuna ilişkin tercihleri Tablo 19'da sunulmuştur. Alıcılara seçenek olarak sunulan, tüm ağaç türlerinde, boy uzunluğu için öncelikli tercihleri $3 \mathrm{~m}$ olarak görülmektedir.

Tablo 19. Alıcıların tomruk boy uzunluğuna ilişkin tercihleri (m)

Table 19. Buyers' preferences regarding timber length

\begin{tabular}{|c|c|c|c|c|c|c|c|c|c|c|c|c|c|c|}
\hline Boylar & \multicolumn{2}{|c|}{$1,5-2 \mathrm{~m}$} & \multicolumn{2}{|c|}{$2,5 \mathrm{~m}$} & \multicolumn{2}{|c|}{$3 \mathrm{~m}$} & \multicolumn{2}{|c|}{$4 \mathrm{~m}$} & \multicolumn{2}{|c|}{$5 \mathrm{~m}$} & \multicolumn{2}{|c|}{$5.5 \mathrm{~m}$ ve üstü } & \multicolumn{2}{|c|}{ Toplam } \\
\hline Ăgaç Türü & Sayı & $\%$ & Sayı & $\%$ & Sayı & $\%$ & Sayı & $\%$ & Sayı & $\%$ & Sayı & $\%$ & Sayı & $\%$ \\
\hline Çam & 16 & 7 & 64 & 26 & 92 & 38 & 51 & 21 & 14 & 6 & 8 & 3 & 245 & 100 \\
\hline Kayın & 10 & 5 & 36 & 19 & 88 & 47 & 41 & 22 & 8 & 4 & 6 & 3 & 189 & 100 \\
\hline Meşe & 8 & 16 & 15 & 31 & 17 & 35 & 7 & 14 & 1 & 2 & 1 & 2 & 49 & 100 \\
\hline Göknar & 11 & 22 & 25 & 23 & 40 & 36 & 24 & 22 & 6 & 5 & 4 & 4 & 110 & 100 \\
\hline
\end{tabular}


Alıcılara satın aldıkları tomruk kalite sınıfı tercihleri sorulmuştur (Tablo 20). Buna göre; ilk sırada III. sinıf tomruk \%78 ile tercih edilen kalite sinıfı olmuştur.

Tablo 20. Alıcıların tomruk kalite sınıfına ilişkin tercihleri

Table 20. Buyers' preferences regarding the round timber quality class

\begin{tabular}{lcccccccccc}
\hline OBM & \multicolumn{2}{c}{ Bursa } & \multicolumn{2}{c}{ Çanakkale } & \multicolumn{2}{c}{ İstanbul } & \multicolumn{2}{c}{ Sakarya } & \multicolumn{2}{c}{ Toplam } \\
\hline Seçenekler & Sayı & $\%$ & Sayı & \% & Sayı & \% & Sayı & \% & Sayı & \% \\
\hline I. Sinıf & 1 & 0 & 4 & 2 & 4 & 2 & 5 & 2 & 14 & 5 \\
II. Sınıf & 1 & 0 & 8 & 3 & - & - & 4 & 2 & 13 & 5 \\
III. Sinıf & 106 & 41 & 20 & 8 & 30 & 12 & 43 & 17 & 199 & 78 \\
Farketmez & 12 & 5 & 8 & 3 & 10 & 4 & 2 & 1 & 32 & 12 \\
Toplam & 120 & 47 & 40 & 16 & 44 & 17 & 54 & 21 & 258 & 100 \\
\hline
\end{tabular}

\subsection{Alıcıların Görüșleri}

Alıcıların, hammadde fiyatları ile ilgili görüşleri sorulmuş ve alınan yanıtlar Tablo 21'de gösterilmiştir. Alınan yanıtlara göre öne çıkan görüşler; \%31 ile fiyatların yüksek olması, $\% 24$ ile vergilerin ve fonların varlığı, \%21 ile fiyat istikrarsızlı̆̆ olmuştur.

Tablo 21. Alıcıların hammadde fiyatlarına ilişkin görüșleri

Table 21. Buyers' opinions of raw material prices

\begin{tabular}{lcc}
\hline Sorunlar & Adet & \% \\
\hline Fiyatların yüksekliği & 82 & 31 \\
Vergilerin ve fonların varlığı & 64 & 24 \\
Fiyat İstikrarsılığı & 56 & 21 \\
KDV hesaplanma şekli & 35 & 13 \\
İthal ürünlerden vergi alınmaması & 10 & 4 \\
Diğer & 18 & 7 \\
Toplam & 265 & 100 \\
\hline
\end{tabular}

Alıcıların hammadde fiyatları ile ilgili görüşleri sorulmuş ve elde edilen yanıtlar OBM'lere göre Tablo Tablo 22'de belirtilmiştir. Fiyatların yüksekliği Bursa OBM'de \%43, Çanakkale ve İstanbul OBM 'de \%21, Sakarya OBM'de \%15 olarak belirtilmiştir. Ayrıca Bursa OBM'de istikrarsızlık problemi \%64 ile öne çıkmaktadır.

Tablo 22. Alıcıların hammadde fiyatlarına ilişkin görüşlerinin OBM'lere göre dağılımı Table 22. Buyers' opinions on raw material prices according to FRDs

\begin{tabular}{|c|c|c|c|c|c|c|c|c|c|c|c|c|}
\hline \multirow{2}{*}{$\begin{array}{l}\text { Tercihler } \\
\text { OBM }\end{array}$} & \multicolumn{2}{|c|}{ İstikrarsızlık } & \multicolumn{2}{|c|}{$\begin{array}{c}\text { Fiyat } \\
\text { Yüksekliği } \\
\end{array}$} & \multicolumn{2}{|c|}{ Vergi ve Fonlar } & \multicolumn{2}{|c|}{ KDV } & \multicolumn{2}{|c|}{$\begin{array}{l}\text { İthal ürünlerden } \\
\text { Vergi alınmaması }\end{array}$} & \multicolumn{2}{|c|}{ Diğer } \\
\hline & Sayı & $\%$ & Sayı & $\%$ & Sayı & $\%$ & Sayı & $\%$ & Sayı & $\%$ & Sayı & $\%$ \\
\hline Bursa & 36 & 64 & 35 & 43 & 32 & 50 & 15 & 43 & 3 & 30 & 8 & 44 \\
\hline Çanakkale & 10 & 18 & 17 & 21 & 7 & 11 & 7 & 20 & - & - & 1 & 6 \\
\hline İstanbul & 4 & 7 & 17 & 21 & 14 & 22 & 4 & 11 & 3 & 30 & 3 & 17 \\
\hline Sakarya & 6 & 11 & 13 & 15 & 11 & 17 & 9 & 26 & 4 & 40 & 6 & 33 \\
\hline
\end{tabular}

Alıcılar, odun hammaddesi temininde etkili olan faktörleri \% 40 ile ürün çeşidi ve kalitesi, \%24 ile fiyat, $\% 14$ ile firmaya yakınlık, \%7 ile standardizasyon, $\% 6$ ile emval boyutları, $\% 5$ ile parti büyüklügü ve $\% 4$ ile depo ulaşım olanakları şeklinde yanıtlamıştır (Tablo 23).

Dikili satış uygulamasını olumlu bulanlar, genel olarak bu satış şeklinin; fiyat bakımından uygun olduğunu, istenilen ebatta ürün temin edilebildiklerini, hammaddenin kesim ve ölçülendirme işinde daha dikkatli olabildiklerini ve istenilen ebatta kesim yapabildiklerini, taze ürün temin edebildiklerini ve adaletli bir uygulama olduğunu dile getirmişlerdir. Dikili satış uygulamasını olumsuz bulanlar, genel olarak bu satış şeklinin; adaletsiz ve büyük sermayeli firmalara yönelik bir uygulama olduğunu, sürdürülebilirlik bakımından hatalı işlemlerin yapıldığını, verim yüzdelerinin düşük veya hatalı hesaplandığını, işletmeleri zarara uğratan bir 
uygulama olduğunu, kontrolünün sağlanamadığını masrafların yüksek olduğunu, stok yapılamadığını, zor bir işlem olduğunu, bu işle ilgili uzmanlaşmış ayrı bir ekibin olması gerektiğini, iş sağlığı ve güvenliği mevzuatından dolayı yaşanılan bürokrasinin zorluğunu ifade etmişlerdir.

Tablo 23. Odun hammaddesi tedarikinde etkili olan faktörler Table 23. Factors affecting wood raw material supply

\begin{tabular}{lcc}
\hline Faktörler & Sayı & \% \\
\hline Ürün çeşidi ve Kalitesi & 106 & 40 \\
Fiyat & 64 & 24 \\
Firmaya Yakınlık & 38 & 14 \\
Standardizasyon & 19 & 7 \\
Emval Boyutları & 16 & 6 \\
Parti Büyüklüğü & 12 & 5 \\
Depo Ulaşım olanakları & 10 & 4 \\
Toplam & 265 & 100 \\
\hline
\end{tabular}

Alıcılar, dikili satış hakkındaki görüşlerini; \%58 ile "olumsuz buluyorum”, \%27 ile "olumlu buluyorum" şeklinde yorumlamıştır (Tablo 24).

Tablo 24. Alıcıların dikili satış hakkındaki görüşleri Table 24. Buyers' opinions of stumpage sales

\begin{tabular}{lcc}
\hline Görüssler & Sayı & \% \\
\hline Olumsuz buluyorum & 154 & 58 \\
Olumlu buluyorum & 71 & 27 \\
Fikrim yok & 40 & 15 \\
Toplam & 265 & 100 \\
\hline
\end{tabular}

\section{Tartıșma ve Sonuç}

Marmara Bölgesinde faaliyet gösteren ve çalışmaya katılan firmalar hukuki yapı itibariyle çeşitlilik göstermekle beraber yapılan çalışmalara benzer olarak tek kişi işletmeleri öne çıkmaktadır. Güney Doğu Anadolu Bölgesi'ndeki işletmelerin büyük bölümünün \%80 limited, kalan kısmın ise \%20 ile tek kişi işletmesi özelliğine sahip olduğu ifade edilmektedir (Çok ve ark., 2017). İl bazında farklı zaman dilimlerinde yapılan çalışmalarda ise tek kişi işletmelerinin diğerlerine göre öne çıktığı ve ikinci sırada limited şirketlerin olduğu görülmektedir (Cındık ve Akyüz, 1998; Demir ve Sütçü, 2002; Kalafat, 2012; Sayılı ve Özbayram, 2015). Kastamonu ilinde yapılan çalışmada ise limited şirketler \%47, tek kişi işletmeleri $\% 28$ ve anonim şirketler ise $\% 25$ oranındadır (Gökçe ve Akyıldız, 2010). Türkiye Odalar Borsalar Birliği (TOBB) veri tabanına kayıtlı birincil imalat sanayi grubunda 1186 işletme bulunmakta ve bunun 531'nin kereste imalatç1sı ve çoğunluğunun küçük ölçekli işletmelerden oluştuğu görülmektedir (Anonim, 2013). Aynı şekilde çalışma kapsamındaki işletmelerin \%65'i birincil imalat sanayi grubundan, en fazla \%32 ile kereste imalatçılarından oluşmaktadır. Ülkemizde kereste endüstrisinde üretim yapan firmaların \%80'i Marmara Bölgesi'nde bulunmakta, bu bölgeyi \%15 ile İç Anadolu Bölgesi izlemektedir (Çelik, 2014). Çalışmaya katılan firmaların \%73'ü KKO açısından \%76100, 18'i \%26-50, \%9'u ise \%51-75 arasında bulunmaktadır. Türkiye'de 2010 yılında tüm orman ürünleri sanayinin KKO \%73,8 düzeyindedir (Strateji ve Bütçe Başkanlığı, 2017). Bu açıdan bakıldığında çalışmaya katılan firmaların büyük çoğunluğunun söz konusu ortalamaya yakın olduğu görülmektedir. Güneydoğu Anadolu Bölgesi için yapılan çalışmada ise KKO’nun daha düşük olduğu tespit edilmiştir (Çok ve ark., 2017).

Alıcıların, endüstriyel odun hammaddesi talebini karşıladıkları kaynaklara bakıldığında Marmara Bölgesinden odun hammaddesi alan müşterilerin odun hammaddesi temin kaynağ $\breve{1}$ ülke verileriyle 
uyumludur. OGM'ye göre ise; Türkiye'de endüstriyel odun hammaddesi talebi \%77 oranında OGM'den, \%15 oranında özel sektör işletmelerinden ve \%8 oranında ise ithalat yoluyla karşılanmaktadır (OGM, 2016b). Güneydoğu Anadolu Bölgesindeki odun işleyen firmalar (alıcılar) endüstriyel odun hammaddesi taleplerini $\% 65$ oranında OGM'den, $\% 21$ oranında ithal ürünlerden ve $\% 14$ oranında ise piyasadaki tüccarlardan sağlamaktadır (Çok ve ark., 2017). Alıcıların, endüstriyel odun hammaddesi talebini ithalat yoluyla karşılama nedenleri sorulduğunda, hammadde fiyatlarının uygunluğu, istenilen kalitede ve zamanda ürün bulma gerekçeleri öne çıkmaktadır. Benzer çalışmalarda da bu türden gerekçelere rastlanmıştır (Çok ve ark., 2017; Kök, 2010). Hammadde fiyatlarının uygunluğu bu çalışmada farklı çıkan bir sonuç olarak görülmektedir. Ülkemizde ormanlardan birinci sınıf orman emvali temininin az olması yanında ithal hammaddenin daha kaliteli ve uygun fiyata bulunabilmesinin bu sonucu doğurduğu ifade edilebilir.

Alıcılar, odun hammaddesi temininde etkili olan faktörler olarak önem sırasına göre; ürün çeşidi ve kalitesi, fiyat, firmaya yakınlık, emval boyutları, depo ulaşım olanakları, standart ve sonuncu olarak da satış parti büyüklügünü öne çıkarmıştır. Benzer çalışmalarda da ilk sırada tercih edilen faktörler ürün çeşidi ve kalitesi olmuştur (Çok ve ark., 2017; Dilsiz, 2008). Öztürk (2010) tarafından, Artvin OBM'de yapılan çalışmada müşterilerin odun hammaddesi alırken dikkat ettikleri ilk üç faktörün sırasıyla; ürünlerin standardizasyona uygunluğu $(\% 55,8)$, emval boyutları $(\% 11,6)$ ve orman deposuna ulaşım imkânları (\%7) olduğu tespit edilmiştir. Daşdemir (2003) tarafından yapılan çalışmada alıcıların isteklerinden \%43'ünün DOİ'lerin özellikle çap ve boy ölçüleri bakımından standartlara uygun mal satması, en fazla şikâyet ettikleri konunun ise ihtiyaçlarını karşılayacak cins ve standartta hammadde bulamama sorunu olduğu şeklindedir.

Alıcıların almak istedikleri ürün çeşidi açısından en önemli tercihleri \%79 ile tomruk, \%36 ile kâğıtlık odun ve \%27 ile sanayi odunu olmuştur. Müşteriler satış parti taleplerini $\% 54$ ile 20-40 m³ $\% 27$ ile 40 $60 \mathrm{~m}^{3}$ olarak belirtmiştir. Alıcıların, daha büyük satış partilerini tercih ettiği anlaşılmaktadır. Benzer çalışmada da (Öztürk, 2010) alıcıların aynı doğrultuda taleplerinin olduğu görülmektedir. Satış parti büyüklükleri tercihlerine bakıldığında; satış partilerinin yükleme aracı kapasitesine göre hazırlanması, pazarlama sürecinde müşteri memnuniyetini artıracağı ve ürün talebine olumlu katkılar sağlayacağı açıktır. Aynı zamanda ihale ilanında çıkan satış parti cetvelleri incelendiğinde, satış partilerinin 20-35 $\mathrm{m}^{3}$ arasında değiştiği görülmektedir. Alıcıların talep ettiği 20-40 $\mathrm{m}^{3}$ 'lük satış partilerinin DOİ'leri tarafından karşılanabildiği söylenebilir.

Alıcılar, OBM'erin hepsinde, emvali satın almak istedikleri aya ilişkin olarak "farketmez" tercihini seçmişlerdir. Çalışmada emvali satın almak istedikleri ay ile ilgili olarak; İstanbul OBM alıcılarının, Ekim-Aralık dönemini daha çok tercih ettiği görülmüştür. Sakarya ve Çanakkale OBM alıcıları tercihen Nisan-Haziran aylarını, Bursa OBM alıcıları ise Nisan-Eylül dönemini tercih etmektedir. Güneydoğu Anadolu Bölgesinde odun işleyen firmalar en fazla Mayıs ve Haziran aylarında odun hammaddesine ihtiyaç duyduklarını belirtmişlerdir (Çok ve ark., 2017). Kök (2010) tarafından yapılan benzer bir çalışmada ise, odun hammaddesi talebinin Mayıs, Haziran ve Temmuz aylarında yoğunlaştığı ifade edilmiştir. Firmaların küçük ölçekli işletmeler olması, bu işletmelerin stok bulundurmaması, üretimlerini siparişe dayalı olarak yapmaları sebebiyle "farketmez" seçeneğinin ön plana çıktığ1 anlaşılmaktadır. Alıcıların satış takviminin düzenlenmesine yönelik tercihlerini \%43 ile "yakın işletme müdürlüklerindeki ihaleler belirli aralıklarla yapılmalı" olarak belirtilmiștir. OGM'nin internet sisteminden ihale takip kısmında yapılan incelemelerde ihalelerde bu sistemin uygulandığ görülmektedir. İşletmelerin ihale takvimi hazırlarken birbirleriyle koordineli çalışmaları gerektiği sonucu ortaya çıkmaktadır.

Alıcılar hammadde fiyatlarıyla ilgili en önemli sorunun; \%31 ile fiyatların yüksekliği, \%24 ile vergilerin ve fonların varlığı olarak belirtmiştir. Bu fonların ithal edilen oduna dayalı orman ürünlerinden 
alınmaması, müşterilerin tepkisine yol açmış ve haksız rekabete sebebiyet verdiği ifade edilmiştir. Oduna dayalı orman ürünü satışlarından alınan "Ağaçlandırma ve Orman Köylülerini Kalkındırma Fon" payları ise 2017 yılında yürürlükten kaldırılmıştır (T.C. Resmî Gazete, 24 Ağustos 2017, Sayı: 30164). Alıcıları ithalata yönelten nedenlerden biri olarak söz konusu fonun ortadan kaldırılması ve hammadde fiyatının düşürülmesi, müşteri istek ve talepleri doğrultusunda bir karar olmuştur.

Alıcıların \%80'i emvali son depodan, \%14'ü rampadan, \%5'i ise maktadan satın almayı tercih etmektedir. Depodan yapılan satışların benzer şekilde yüksek çıktı̆̆ Güneydoğu Anadolu Bölgesi için yapılan çalışmada, firmaların tamamına yakını (\%97) DOİ 'den hammadde temininde depodan yapılan satışları tercih etmiştir (Çok ve ark., 2017). Giresun OBM 20092012 yıllarını kapsayan 4 yıllık dönemdeki satışların incelendiği çalışmada ise, açık artırmalı satışların sadece \%8'inin dikili, \%82'sinin ise depodan yapılan satışı tercih ettiği belirtilmiştir (Komut ve Öztürk, 2014). Bununla birlikte, dikili satış uygulamalarına yönelik olarak, OGM, OR-KOOP, orman köylüleri ve orman endüstrisi ilgi grupların teknik, sosyal ve yönetsel boyutlarda olumsuz bir algıya sahip olduğu ifade edilmiştir (Gültekin, 2015). Ayrıca, özellikle firmaların araç, gereç, ekipman ve teknoloji gibi imkanlara sahip olmamalarından kaynaklı odun üretimi ve taşıma işlerinde yaşanması muhtemel sorunlar bu noktada dikili satışlara olan talebi olumsuz yönde etkileyebilmektedir (Daşdemir, 2011). Alıcıların \%59 oranında dikili satışı olumsuz bulması da benzer sorunları içermektedir. Alıcıların \%27' si dikili satışı olumlu bulduğunu belirtmiş̦tir. Bu sonuçlar Marmara Bölgesinden odun hammaddesi satın alan alıcıların, dikili satış tercihinin düşük olduğunu göstermektedir. Bununla birlikte, dikili satışı olumsuz bulan alıcıların, teknik ve yönetsel olarak söz konusu satış şekline uygun olmayan küçük işletmelerden oluşmasının bu sonuçta etkili olduğu düşünülmektedir.

Alıcıların önemli bir kısmı, satış partilerinin oluşturulmasında ince çaplı ve kalın çaplı emvallerin ayrı ayrı partilerde yer almasını \%88 oranında tercih etmişlerdir. İnce çaplı ve kalın çaplı emvaller aynı satış partisinde karışık yer almalıdır tercihini yapanların oranı ise \%12'dir. Öztürk (2010) tarafından yapılan çalışmada alıcıların önemli bir kısmının satış partilerinin oluşturulmasında ince çaplı ve kalın çaplı emvallerin ayrı ayrı partilerde yer almasını \%91,8'i belirtmiştir. Buna karşılık, \%8,2'i çap açısından karışık özellik gösteren istifleri tercih ettiğini ifade etmiştir. Alıcıların satış istiflerinin çap açısından homojen nitelikte olması yönündeki tercihleri benzer çalışmalarla da ortaya konulmuş durumdadır.

Alıcılar, satış partilerinin oluşturulmasında emval boylarına ilişkin olarak \%61 oranında satış partilerinin tek boydan oluşmasını tercih etmektedirler. Buna karşın, satış partilerinin tüm boylardan oluşmasını ifade edenlerin oranı \%39'dur. Öztürk (2010) tarafından yapılan çalışmada alıcıların \%48,9'u partilerin tek boydan oluşmasını tercih etmiştir. Tüm boylardan ürün bulunması yönünde görüş beyan edenler ise $\% 46,8$ oranındadır. Bu çalışmada satış partilerinin tüm boylardan oluşmasını tercih edenlerin oranının daha yüksek çıktığı görülmektedir. Genel olarak firmaların çoğunluğunun gerek boy ve gerekse çap özellikleri açısından aynı grupta yer alan emvalleri satın almak istedikleri Çok ve ark., (2017) tarafından yapılan çalışmada da belirtilmiştir.

Alıcılar, tomruk kalite sınıfı tercihlerini \%78 ile üçüncü sınıf tomruk olarak belirtmiştir. Diğer kalite sınıfi tercihleri \%10, kalite sınıfını önemsemeyenler ise \%12 oranındadır. Ülkemiz ormanlarının \%15'i birinci ve ikinci sınıf tomruk üretilebilme potansiyeline sahip olduğu bilinmesine rağmen, uygulamada $\% 0,5$ ile birinci sınıf ve \%3,5 ile ikinci sınıf tomruk üretilmekte, kalan \%96'lık kısım ise en düşük kalite sınıfi olan üçüncü sınıf tomruk olarak üretilmektedir (OGM, 2016b). Alıcıların kalite sınıfını önemsemeyen \%12'si ile birlikte \%90 oranında üçüncü sınıf ve düşük kalite tomruk tercih ettikleri belirlenmiştir. Bu sonucu destekleyen bir başka çalışmada da en fazla üçüncü sınıf emvallerin satışının olduğu bildirilmektedir (Kök, 2010). Yine Daday DOİ'de 2014 yılında yapılan açık artırmalı satışlara konu ürünlerin \%80,70’i üçüncü sınıf tomruk, \%19,30’u ikinci sınıf tomruk olarak gerçekleşmiş ve söz konusu yılda satışlarda birinci sınıf tomruk yer almamıştır (Özden ve Buğday, 2015). 
Alıcıların ağaç türleri itibariyle tomruk boy uzunluğuna ilişkin tercihlerinde $3 \mathrm{~m}$ boy uzunluğunun öne çıktığı görülmektedir. Benzer şekilde Çok ve ark. (2017) tarafından yapılan çalışmada da firmaların en fazla satın aldıkları endüstriyel odun boyunun 3-6 m arasında değiştiği ve bu aralıkta da en fazla 3 ve 4 metrelik endüstriyel odunların satın alındığı belirtilmektedir. Kök'ün (2010) çalışmasında da tüm ağaç türleri için normal boy grubundaki tomruklardan en fazla tercih edilen boyun $3 \mathrm{~m}$ olduğu belirlenmiştir. Marmara Bölgesindeki odun hammaddesi satın alan müşteriler için de 3 metrelik normal boy tercih edilen boy grubu olmuştur.

Son dönemde gittikçe artan rekabet koşullarında üretim yapan OGM'nin, üretime yönelik anlayıştan uzaklaşmak, müşteri odaklı hareket edebilmek, satışlarında iyi fiyat düzeylerini yakalamak, üretimini zamanında gerçekleştirmek ve istenilen kalite ve standartta mal üretebilmek adına yeni bir sisteme ihtiyacı olduğu açıktır. OGM'nin, müşterilerin beklenti ve istekleri doğrultusunda üretim yapmayı amaçlaması, üretim odaklı bir anlayış yerine müşteri odaklı bir anlayışa geçmesi ve bu doğrultuda tüm bölge müdürlükleri ile beraber pazarlama anlayışını geliştirebilen bir politika izlemesi gerekmektedir. Böylelikle OGM'nin rekabet edebilirlik açısından güçleneceği öngörülmektedir.

\section{Teşekkür}

Bu makale, Orman Genel Müdürlüğü, Marmara Ormancilık Araştırma Enstitüsü Müdürlüğü’nce desteklenen 10.5303 numaralı "Devlet Orman Işsletmelerinden Odun Hammaddesi Satın Alan Müşterilerin Sorunlarının ve Beklentilerinin Belirlenmesi: Marmara Bölgesi Örneği” adlı projeden hazırlanmıştır. Çalışmanın ortaya çıkmasına destek veren tüm katılımcılara teşekkür ederiz.

\section{KAYNAKÇA}

Anonim, (2013). Türkiye Orman Ürünleri Meclisi Sektör Raporu 2013, Türkiye Odalar ve Borsalar Birliği Türkiye Orman Ürünleri Meclisi, TOBB Yayın No: 2015/246, ISBN: 978-605-137-461-1 Ankara.

Anonim, (2012). SPSS, Bilgisayar program1, Institute Inc. 2012. SPSS Base 21.0 User’s Guide.

Bilgin, F., Ay, Z., Akkaya, M. (2002). Ege Bölgesi Oldun Kökenli Ürün Sanayinin Mevcut Durumu ve Gelişim Potansiyeli. Orman Bakanlığı Yayın No: 156, Müdürlük Yayın No: 022, ISSN 1300-9508, Ege Ormancılık Araştırma Müdürlüğü Teknik Bülten No: 16, İzmir.

Buğday, S.E., (2016). Oduna Dayalı Orman ürünlerinde Stratejik Pazalama Analizi. Çankırı Karatekin Üniversitesi Fen Bilimleri Enstitüsü, Basılmamış Doktora Tezi.

Cındık, H., Akyüz, K.C., (1998). Trabzon İlindeki Küçük ve Orta Ölçekli Orman Ürünleri Sanayi İşletmelerinin Yapısı, Sorunları ve Çözüm Önerileri, Tr. J. of Agriculture and Forestry 22 (1998) 7-11.

Çelik, N. (2014). Orman Ürünleri Sanayii, Ar\&Ge Bülten, 2014 Temmuz - Sektörel, İzmir Ticaret Odas1, http://www.izto.org.tr/portals/0/argebulten/2014temmuzormanurunleri.pdf [Erişim Tarihi:21 Temmuz 2018]

Çok, N., Öztürk, A.,Okur, A., Polat, O., Pak. M., Doğaner, A. (2017). Odun işleyen firmaların endüstriyel odun hammadde temin sürecinin araştırılması (Güneydoğu Anadolu Bölgesi örneği). Ormancılık Araştırma Dergisi, 2017, 4,1, 61-76.

Daşdemir, İ. (2001). Bartın ve Yenice Orman İşletmelerinde Açık Artırmalı Göknar Tomruk Satış Fiyatını Etkileyen Faktörler, ZKÜ Bartın Orman Fakültesi Dergisi, Yayın no:3,118-136 s., Bartın.

Daşdemir, İ. (2003). Asli Orman Ürünlerinde Fiyat Analizi (Zonguldak Orman Bölge Müdürlüğü Örneği), Bartın Orman Fakültesi Dergisi, Üniversite Yayın No: 26 Fakülte Yayın No: 12, 119 s., ISBN 978-7138-22-7 Bartın.

Daşdemir, İ. (2011). Dikili Ağaç Satışlarının Uygulanması Üzerine Değerlendirmeler, Bartın Orman Fakültesi Dergisi 2011, Cilt: 13, Say1: 20, 71-79 ISSN: 1302-0943 EISSN: 1308-5875.

Daşdemir, İ. (2016) Bilimsel Araştırma Yöntemleri, Nobel Akademik Yayıncılık, ISBN: 9786053204428, 218 s., Ankara. 
Demir, Y., Sütçü, A., (2002). Kriz Sonrası Isparta Orman Endüstri KOBİ'lerinin Üretim, Teknoloji ve Finansman Sorunlarının Analizi, Süleyman Demirel Üniversitesi Orman Fakültesi Dergisi Seri: A, Sayı: 2, Y1l: 2002 , Sayfa:79-96.

Dilsiz, K., S. (2008). Devlet Orman İşletmelerinde Müşteri Tatmininin Ölçümü ve Pazarlama Yönetimi, İ.Ü. Fen Bilimleri Enstitüsü, Basılmamış Yüksek Lisans Tezi, İstanbul.

Gökçe, A., Ayyıldız, H. (2010). Kastamonu İli Orman Ürünleri Endüstrisi, Kastamonu Üniversitesi., Orman Fakültesi Dergisi, 10 (2): 147-163.

Gültekin, Y.S. (2015). Devlet Orman İşletmelerinde Dikili Ağaç Satışı Uygulamasının Yapısal Eşitlik Modellemesi İle Analizi, Düzce Üniversitesi Fen Bilimleri Enstitüsü Orman Mühendisliği Anabilim Dalı, Basılmamış Doktora Tezi, Düzce.

İlter, E. ve Ok, K. (2012). Ormancılık ve Orman Endüstrisinde Pazarlama İlkeleri ve Yönetimi, HTC Matbaacılık, ISBN: 978-975-96967-5-7, Ankara.

Kalafat, N., 2012, Balıkesir İli Orman Endüstri İşletmelerinin Sosyo-Ekonomik Anali-zi. Bartın Üniversitesi, Fen Bilimleri Enstitüsü, Orman Endüstri Mühendisliği Anabilim dalı, Yüksek Lisans Tezi, Bartın.

Strateji ve Bütçe Başkanlığı, 2018. 11. Kalkınma Planı 2019-2023, İmalat Sanayii Politikaları Özel İhtisas Komisyonu Raporu, Yayın No: KB:3031-ÖİK:813, Ankara.

Komut, O., Öztürk, A. (2014). Dikili Ağaç Satışı Uygulamasının Yerel Piyasadaki Rekabete Etkileri, II. Ulusal Akdeniz Orman ve Çevre Sempozyumu "Akdeniz ormanlarının geleceği: Sürdürülebilir toplum ve çevre" 22-24 Ekim 2014, Bildiriler Kitabı, 1068-1074, Isparta.

Kök, G. (2010). Orman İşletmelerinin Odun Ham maddesine İlişkin Müşteri Profilinin ve Talep Yapısının Belirlenmesi: Antalya Orman Bölge Müdürlüğü Örneği. SDÜ FBE, Basılmamış Yüksek Lisans Tezi, Isparta.

Sayılı, M., Özbayram, M. (2015). Tokat İlinde Orman Ürünleri Endüstrisinin Mevcut Durumu, Sorunları ve Çözüm Önerileri. Çankırı Karatekin Üniversitesi, Sosyal Bilimler Enstitüsü Dergisi, 6(1).

T.C. Resmî Gazete, Oduna Dayalı Orman Ürünü Satışlarından Alınan Fon Paylarının Belirlenmesi Hakkında Karar. 24 Ağustos 2017, Sayı: 30164, Ankara.

Ok, K. (1997). Devlet Orman İşletmelerinin Açık Artırmalı Satışlarının Etkileşimi. DOA Dergisi, No 3, s.41-61, Tarsus.

Orhunbilge, N., 2000, Tanımsal İstatistik, Olasılık ve Olasılık Dağılımları, İşletme Fakültesi yayın No:279, Avc1ol Basım, İstanbul.

OGM, 2016a, Orman Genel Müdürlüğü Stratejik Plan (2017-2021), Ankara.

OGM, 2016b, Oduna Dayalı Orman Ürünlerinin Üretim ve Pazarlama Faaliyetleri, Orman Genel Müdürlüğü İşletme ve Pazarlama Dairesi Başkanlığı, Ankara.

Öztürk, A. (2010). Artvin Orman Bölge Müdürlüğü Açık Artırmalı Satışlarına Katılan Müşterilerin Talep ve Beklentilerinin Belirlenmesi. Artvin Çoruh Üniversitesi Orman Fakültesi Dergisi, 11 (2):61-73, Artvin.

Özden, S., Erkan Buğday, S. (2015). Türkiye'de Orman Ürünleri Pazarında TSE Standartları, IV. Ormancılıkta Sosyo Ekonomik Sorunlar Kongresi, 15-17 Ekim 2015, Trabzon, Bildiriler Kitabı, 285-297.

Özen, M., Alkan, H. (2020). Devlet Orman İşletmelerinde Müşteri Memnuniyetinin Belirlenmesi (Isparta Orman Bölge Müdürlüğü Örneği). Turkish Journal of Forestry, 21(3):267-278, DOI: 10.18182/tjf.750471, Isparta.

Türker, M.F., (1995). Orman İşletmelerinde Pazarlama Anlayışı ve Orman Ürünlerinde Fiyatlandırmanın Kritiği, KTÜ Orman Fakültesi Bahar Yarılı Seminerleri, Fakülte Yayın No: 49, s. 90-94, Trabzon. 
Türker, M.F. (1996). Açık Artırmalı Orman Ürünleri (Tomruk) Satışlarında Fiyat Oluşumunun Araştırılması (Doğu Karadeniz Bölgesi Örneği), KTÜ Araştırma Fonu 93.115.002.1 Kod numaralı Proje, 106 sayfa, Trabzon.

Başvuru tarihi: 08.11.2020 Yayına Kabul edildiği tarih: 28.12.2020 